\title{
The concept of public health. Types of health systems. Parallel between the Romanian and the Australian health system
}

\author{
Conceptul de sănătate publică. Tipuri de sisteme de sănătate. \\ Paralelă între sistemul de sănătate românesc şi cel australian
}

\author{
Dorel Dulău' ${ }^{1,2}$, Simona Bungău', Lucia Daina ${ }^{1,3}$, Camelia Buhaş,1,4, \\ Ioana Anca Balaşco ${ }^{2}$, Petre Cotrău ${ }^{1}$, Monica Elena Reştea (Iosub) ${ }^{1}$ \\ ${ }^{1}$ Facultatea de Medicină şi Farmacie, Universitatea din Oradea, România \\ ${ }^{2}$ Primăria Municipiului Oradea, România \\ ${ }^{3}$ Spitalul Clinic Judeţean de Urgenţă, Oradea, România \\ ${ }^{4}$ Serviciul Judeţean de Medicină Legală Bihor, România
}

\begin{abstract}
Medical management is a field that combines, both in theory and in practice, two somewhat different domains, administration and the medical domain, creating a third area of activity, namely that of medical management. This review is part of a study of health services management, which seeks to find solutions to improve the efficiency of the the management and administration of the medical system, both locally and nationally.

In order to be able to study and evaluate, from a scientific point of view, the concepts of centralization and decentralization of the public health system in Romania, it is absolutely pertinent, but also mandatory, to focus on defining the notion of health system. Only later can we approach and research the process of decentralization of health, the political and economic context in which it can be initiated, as well as how to activate and carry it out. Decentralization, as a phenomenon of the transfer of rights and obligations, from the level of the central authority to the level of the local authority, can take various forms. From a theoretical and practical point of view, the forms of decentralization can be studied, evaluated and concluded by emphasizing the strengths and weaknesses. Also important to study are the ways of putting health systems into practice, which from the point of view of the source of funding are divided into state-funded health systems (Semashko, Beveridge and Bismarck) and privately funded health systems.
\end{abstract}

Keywords: centralization, decentralization, health systems, hospitals

\begin{abstract}
REZUMAT
Managementul medical reprezintă un domeniu care îmbină atât în teorie, cât şi în practică două specialităţi oarecum diferite, respectiv cea a administraţiei cu cea medicală, creând o a treia zonă de activitate, cea a managementului medical. Prezentul articol face parte dintr-un studiu dedicat managementului serviciilor de sănătate, care încearcă să găsească soluţii de eficientizare a modalităţii de gestionare şi administrare a sistemului medical, atât la nivel local, cât şi la nivel naţional.

Pentru a putea studia, evalua şi sintetiza, din punct de vedere practic, dar şi teoretic, conceptele de centralizare şi descentralizare ale sistemului de sănătate publică din România, este absolut pertinent, dar şi obligatoriu, să ne aplecăm asupra definirii noţiunii de sistem de sănătate. Abia ulterior putem aborda şi cerceta procesul de descentralizare a sănătăţii, contextul politic şi economic în care a fost iniţiat, precum şi modalitatea de desfăşurare a acestuia. Descentralizarea, ca fenomen al transferului de drepturi şi obligaţii de la nivelul autorităţii centrale la nivelul autorităţii administrative locale, poate îmbrăca diverse forme. Din punct de vedere teoretic, dar şi practic, formele descentralizării pot fi studiate, evaluate şi concluzionate prin sublinierea punctelor tari şi a punctelor slabe. Totodată, important de studiat sunt şi modalităţile de transpunere în practică a sistemelor de sănătate, care, din punctul de vedere al sursei de finanţare, se impart în sisteme de sănătate cu finanţare de la bugetul de stat (Semashko, Beveridge şi Bismarck) şi sisteme de sănătate cu finanţare private.
\end{abstract}

Cuvinte cheie: centralizare, descentralizare, sisteme de sănătate, spitale 


\section{INTRODUCERE}

Anul 2010 a reprezentat, pentru ţara noastră un an plin de semnificaţii, atât din punct de vedere administrativ, cât şi din perspectiva reformei sistemului medical.

La vremea respectivă, sistemul de sănătate din România, construit şi fundamentat pe principiile de funcţionare instituite de academicianul rus Semashko, reprezenta un monolit aflat în totală subordonare, coordonare şi gestionare faţă de Ministerul Sănătăţii şi guvernul României. Ca un detaliu semnificativ, dar în acelaşi timp relevant, în privinţa funcţionării sănătăţii publice în România, se poate preciza că în anul 2010 existau şi îşi desfăşurau activitatea 435 de spitale, toate având în fruntea lor câte un manager, care, la rândul lui, deţinea un contract de management încheiat şi semnat direct cu ministrul Sănătăţii $(1,2)$.

Indiferent de capacitatea intelectuală şi fizică a ministrului Sănătăţii, anul 2010 reliefează o stare de fapt care evidenţia imposibilitatea unei singure persoane de a supraveghea un număr atât de mare de spitale, de a evalua indicatorii de performanţă încheiaţi cu managerii celor 435 de spitale, de a supraveghea din punct de vedere medical, administrativ şi financiar modul în care se desfăşoară activitatea unităţilor sanitare $(3,4)$.

Printr-o punere în paralel a sistemului de sănătate descentralizat din România cu cel din Australia, putem evidenţia şi descoperi ceea ce trebuie îmbunătăţit în organizarea şi funcţionarea sistemului medical românesc $(5,6)$.

\section{MATERIAL ŞI METODĂ}

În realizarea acestui articol, având ca temă sistemele de sănătate funcţionale şi formele de transpunere în practică a noţiunii teoretice de descentralizare, am folosit metoda analizei, completată de metoda comparaţiei dintre sistemele de sănătate din ţara noastră şi din Australia. Datele sunt obţinute din documente oficiale emise de autorităţi ale administraţiei publice locale din România (dispoziţii ale instituţiei primarului, hotărâri ale Consiliilor locale), ale Ministerului Sănătăţii, ordine de ministru, documente din legislația australiană, precum şi articole din literatura internaţională pe tema sistemelor de sănătate.

\section{DEFINIREA CONCEPTULUI DE SISTEM DE SĂNĂTATE}

Premergător definirii noţiunii de sistem de sănătate, este indicat să caracterizăm sensul conceptului de sănătate publică.
Prima formă eficientă a unui program sau plan de sănătate publică, ca proiect bine sistematizat din punctul de vedere al concepţiei, dar şi al pragmatismului, care urmăreşte succesul acţiunii, aspectele practice şi utilitatea, s-a conturat prin preocuparea colectivă de drenare a tuturor mlaştinilor din zonele locuite, pentru a scăpa de ţânţarii purtători ai malariei.

Moise Maimonide a fost filozof şi teolog evreu, medic personal al sultanului Egiptului şi Siriei pe nume Saladin, iar meritul său în domeniul medical a fost cuantificat în urma alcătuirii unei culegeri cu 10 dizertaţii medicale.

Totuşi, literatura de specialitate medicală îl recunoaşte pe Hipocrate, unul dintre cei mai vestiţi medici ai Greciei antice, ca fiind întemeietorul şcolii hipocratice de medicină, precum şi adevăratul părinte al medicinei.

Încă din perioada Antichităţii, medicul grec Hipocrate a elaborat o carte de învăţătură pentru populaţia vremii respective, denumită ,Aerul, apele şi locurile", care definea relaţiile existente între mediul înconjurător şi diferite boli umane. Această operă cu caracter medical, apărută într-o formă incipientă, în funcţie de informaţiile şi descoperirile limitate din acea perioadă, a reprezentat o lucrare ştiinţifică cu tentă medicală, de căpătâi pentru literatura de specialitate, până în jurul anilor 1800, când ştiinţa medicală a căpătat noi arii şi sensuri în dezvoltarea ei.

Revenind la perioada actuală, o formă precisă şi contemporană zilelor noastre a conceptului de sănătate publică este definită ca ,un mecanism social care transformă resursele generale în produse specializate sub forma serviciilor de sănătate, cu scopul diminuării poverii bolii sau a consecinţelor ei (incapacitate, invaliditate, deces prematur)“ $(7,8)$.

\section{TIPURI DE SISTEME DE SĂNĂTATE}

Sistemele de sănătate cu finanţare de la bugetul de stat au căpătat denumiri în funcţie de personalităţile care au contribuit la înfiinţarea şi funcţionarea lor: Semashko, Beveridge şi Bismarck. Al patrulea sistem, care nu poartă denumirea unei personalităţi, este sistemul de sănătate privat $(9,10)$.

România, ca stat independent, în perioada imediat următoare Revoluţiei din decembrie 1989, era organizată sub forma unui stat centralizat, iar stilul de organizare a sistemului medical era constituit după sistemul de tip Semashko (conform unui raport al Comisiei constituite prin Ordinul MS 241/2011) (11). 


\section{Sistemul de sănătate de tip Semashko $(12,13)$}

Sistemul de tip Semashko are la bază câteva principii fundamentale în baza cărora se constituie modalitatea de funcţionare:

- serviciile medicale sunt în totalitate proprietatea statului;

- personalul medical este angajat al statului, calitatea medicilor şi asistenţilor medicali fiind aceea de funcţionari publici;

- sursa de finanţare a sistemului de sănătate publică se fundamentează, în principal, pe veniturile de la bugetul de stat, venituri obţinute din taxele generale, din impozite etc.;

- aşa-zisa gratuitate a serviciilor medicale prestate pacienţilor este un lucru total fals; de fapt, actul medical nu este plătit de către pacient;

- sistemul medical este uniformizat, la nivel naţional fiind eliminată total competiţia dintre prestatorii de servicii medicale de stat;

- insuficienta susţinere, din punct de vedere financiar şi bugetar, a sistemului medical afectează calitatea actului medical;

- accesul în mod egal al tuturor cetăţenilor la serviciile medicale de stat.

\section{Sistemul de sănătate de tip Beveridge (14)}

În anul 1942, comisia condusă de Beveridge a finalizat raportul, în baza obiectivelor care au fost stabilite de către guvern, înaintându-1 Parlamentului britanic spre dezbatere publică şi eventuale observaţii sau amendamente. Ideea în jurul căreia Beveridge a construit o întreagă politică de asigurări sociale a fost aceea prin care toate persoanele apte de muncă să participe sub forma unei contribuţii săptămânale, care să ajungă la bugetul global de stat, din care se vor deconta serviciile de sănătate pentru persoanele bolnave, femeile rămase singure fără soţ şi venit, oameni fără locuri de muncă etc.

Principalele caracteristici ale modului de organizare al sistemului de sănătate creat de Beveridge sunt:

- sursa principală de finanţare este bugetul de venituri şi cheltuieli al statului. Sumele se repartizează direct de către Ministerul Sănătăţii pe fiecare regiune/zonă administrativă locală;

- asigură acoperirea întregii populaţii a ţării, în privinţa serviciilor medicale, cu menţiunea că persoanele cu risc medical (boli cronice, vârstă înaintată etc.) au întotdeauna prioritate;

- asigurarea către populaţie a liberului acces la serviciile de sănătate, acces bazat pe con- tribuţiile obligatorii plătite statului, dar şi pe alte contribuţii pe venituri gestionate de către stat;

- medicii de familie sunt plătiţi în funcţie de numărul de pacienţi înscrişi pe listele proprii, aşa-zisa plată ,per capita“;

- salariaţii spitalelor sunt plătiţi direct de la bugetul de stat;

- contravaloarea serviciilor medicale se decontează ulterior prestării actului terapeutic.

Modalitatea finanţării specifice sistemului de tip Beveridge, implementată în Marea Britanie în anul 1944, s-a extins şi a devenit aplicabilă şi în alte ţări, cum sunt Danemarca, Islanda, Norvegia, Finlanda, Suedia, Grecia, Portugalia, Italia etc.

\section{Sistemul de sănătate de tip Bismarck}

Acest tip de sistem reprezintă un cadru organizaţional ce poartă o puternică amprentă a stilului de funcţionare german în asigurările sociale de sănătate. Acest cadru sistemic se bazează pe următoarele principii:

- bugetul de finanţare a unităţilor sanitare se elaborează, constituie şi dezvoltă atât pe baza contribuţiilor obligatorii impuse în mod legal cetăţenilor, cât şi pe subvenţiile primite din partea bugetului naţional de stat. Contribuţiile obligatorii sunt percepute atât angajaţilor, cât şi angajatorilor. Acestea se încasează sub forma unor procente fixe aplicate cuantumului salarial brut, deci contribuţiile individuale atât ale angajaţilor, cât şi ale angajatorilor sunt variabile ca sume. Stabilirea procentuală este determinată prin politica guvernului în exerciţiu, dar depinde şi de potenţialul economic al ţării respective (15).

- gestionarea finanţelor din domeniul sanitar se pune în aplicare atât prin intermediul autorităţilor funcţionale la nivel naţional, cât şi prin instituţiile abilitate la nivelul autorităţilor administrative locale, adică atât printr-o casă de asigurări de sănătate cu competenţe naţionale, independentă de guvern, cât şi prin casele de asigurări de sănătate active la nivel regional/local;

- politica de sănătate publică, în ansamblul ei, este gestionată la nivelul guvernului, cu sprijinul de specialitate al Ministerului Sănătăţii şi al Casei de Asigurări de Sănătate, acestea reprezentând autorităţile specializate şi competente în politica sectorului medical (16).

Sistemul de asigurări sociale de tip Bismarck a fost fundamentat în anul 1893 în Germania, ulteri- 
or devenind aplicabil în mai multe ţări: Austria, Belgia, Israel, Luxemburg, Turcia, Franţa, Olanda, Elveția şi România.

\section{Sistemul de sănătate privat}

A patra formă de sistem de sănătate care are la bază criteriul finanţării este reprezentată de sistemul privat. De-a lungul timpului, sistemul de finanţare a creat două grupări de sisteme de sănătate, care au dus ulterior la formarea a două mari curente de opinie, etatiştii şi adepţii liberalismului excesiv (17).

Pe de-o parte, etatiştii consideră sistemul privat drept o căpuşă a sistemului public şi îl blamează ca pe o concurenţă neloială, şi, pe de altă parte, adepţii liberalismului excesiv idealizează sistemul privat şi îl consideră singura alternativă reală la sistemul public (18).

Sistemul de sănătate cu finanţare privată, deşi poate fi acuzat ca fiind setat pe profit, ca orice organizatie privată, totuşi, oferă o libertate mai mare de alegere a serviciilor medicale de pe piaţă. De asemenea, spitalele private pot elimina din cadrul serviciilor medicale birocraţia excesivă şi timpii de aşteptare specifici spitalelor publice de stat.

Totuşi, sistemul privat nu este întotdeauna accesibil persoanelor cu venituri reduse sau vârstniclor, ca urmare a costurilor ce trebuie achitate ca contravaloare a serviciilor medicale sau farmaceutice prestate. Resursa umană, în mod special categoria profesională a medicilor, este bine drămuită în sectorul privat, evitându-se anumite situaţii întâlnite în spitalele publice de stat, unde uneori medicii şi conducătorii de spitale depăşesc limita necesară legalizată prin normativul în vigoare (5).

\section{PARALELĂ ÎNTRE SISTEMUL DE SĂNĂTATE ROMÂNESC ŞI CEL AUSTRALIAN}

Anul 1984 reprezintă geneza iniţierii şi dezvoltării unui sistem de asigurări de sănătate, cu caracter universal, denumit caracteristic MEDICARE, în Australia (19).

Acest sistem are la bază câteva principii de funcţionare şi organizare, respectiv: simplitate, echitate, accesabilitate şi universalitate. Astfel, întreaga populaţie a statului australian are la bază accesul liber şi necondiţionat la sistemul public de sănătate MEDICARE. Guvernul naţional asigură finanţarea suficientă în privinţa MEDICARE, iar conducerile celor 6 state şi 2 teritorii (forme administrative de organizare ale Australiei) au obligaţia de a susţine prestarea serviciilor de sănătate, atât în regim spitalicesc, cât şi în sistem ambulatoriu, către întreaga populaţie.
Accesul întregii populaţii la sistemul de sănătate MEDICARE a dus la unele situaţii care au generat liste de aşteptare ale pacienților care solicitau accesul la serviciile medicale spitaliceşti şi ambulatorii.

Listele de aşteptare şi dorinţa pacienţilor de a le evita au dus la dezvoltarea unui sistem de asigurări medicale private într-un procent substanţial care ajunge la aproximativ $31 \%$ din populaţia australiană. Totodată, $25 \%$ dintre paturile aprobate la nivel naţional se află în spitalele cu finanţare privată.

Sistemul MEDICARE a stabilit şi un pachet standardizat de servicii de sănătate la care populaţia are acces în baza asigurării de sănătate (20).

Ca urmare, anual, se publică pachetul de servicii medicale standardizat MEDICARE, unde sunt enumerate procedurile medicale, beneficiile în privinţa medicamentelor şi serviciile cu caracter medical care pot fi prestate.

Finanţarea sistemului de sănătate australian are la bază o formulă de calcul intitulată "Casemix", formulă care face ca spitalele să primească bugetul efectiv în funcţie de numărul internaţilor. Ca urmare, cu cât numărul internaţilor în unităţile sanitare cu paturi este mai mare, cu atât banii primiţ̧i de spitale de la Comisia de Asigurări de Sănătate din Australia sunt mai mulţi. De aceea, există riscul ca mulţi pacienţi care pot fi trataţi în sistem ambulatoriu să fie internaţi în cadrul spitalului doar pentru a primi finanţare suplimentară în buget.

Sistemul de asigurări de sănătate din România copiază, în mare parte, sistemul australian, cel puţin în privinţa finanţării.

În privinţa asigurărilor obligatorii, taxele procentuale aplicate asupra veniturilor brute, percepute atât de la angajatori, cât şi de la angajaţi, se constituie ca venituri la bugetul asigurărilor de sănătate. Acest buget reprezintă principala sursă de subvenţionare a spitalelor publice de stat din România, care prestează atât servicii spitaliceşti, cât şi ambulatorii.

O alternativă la sistemul medical public de stat o reprezintă sistemul medical privat din România. La fel ca şi în Australia, lista de aşteptare în privinţa programărilor la servicii medicale poate fi evitată prin accesarea spitalelor cu finanţare privată, unde plata serviciilor medicale se face direct de către pacient. Sistemul medical privat românesc, la fel ca şi cel australian, poate constitui şi ajuta inclusiv la decongestionarea spitalelor publice de stat, atât din punct de vedere medical şi operaţional, cât şi din punct de vedere bugetar (21).

Din datele actuale, se constată că sistemul de finanţare spitalicesc românesc se suprapune celui 
din Australia, fapt care denotă că majoritatea cauzelor subfinanţării sistemelor de sănătate din cele două ţări sunt comune (22).

Spitalele din România sunt racordate la mai multe surse de finanţare, dintre care cea mai importantă este cea care are la bază contractul cu Casa de Asigurări de Sănătate. De asemenea, bugetul spitalelor poate fi completat cu alocări bugetare de la autorităţi guvernamentale centrale sau locale, de la Ministerul Sănătăţii, cu bani de investiţii în clădiri, dar şi în dotarea cu aparatură medicală performantă, precum şi cu propriile venituri obţinute din prestarea unor servicii medicale directe către firmele private.

În Australia, la fel ca şi în Canada, s-a dezvoltat un sistem naţional de finanţare, la care se participă cu contribuţii atât din partea bugetului federal, cât şi de la bugetul fiecărui stat şi teritoriu australian în parte.

Conflict of interest: none declared

Financial support: none declared

\section{BIBLIOGRAFIE}

1. Hotărârea Consiliului Local al Municipiului Oradea nr. 401 din 14 iunie 2010 privind trecerea în subordinea Municipiului Oradea a următoarelor unităţi sanitare: Spitalul Clinic Municipal „dr. Gavril Curteanu”, Spitalul Clinic de Obstetrică Ginecologie, Spitalul Clinic de Neurologie şi Psihiatrie şi Spitalul de Pneumoftiziologie.

2. Ordonanţa de urgenţă nr. 48 din 2 iunie 2010, pentru modificarea şi completarea unor acte normative din domeniul sănătăţi în vederea descentralizării.

3. Hotărârea Consiliului Local al Municipiului Oradea nr. 401 din 14 iunie 2010 privind trecerea în subordinea Municipiului Oradea a următoarelor unităţi sanitare: Spitalul Clinic Municipal „Dr. Gavril Curteanu”, Spitalul Clinic de Obstetrică Ginecologie, Spitalul Clinic de Neurologie şi Psihiatrie şi Spitalul de Pneumoftiziologie.

4. France G, Taroni F. The Evolution of Health-Policy Making in Italy. Journal of Health Politics Policy and Law. 2005;30(1-2):169-87.

5. Roger France FH, Mertens I, Closon MC et al. Case-Mix: Global views, Local Actions. Brugge: IOS Press Ebooks, 2001.

6. Hotărârea de guvern nr. 303 din 23 martie 2011 pentru aprobarea Strategiei naţionale de raţionalizare a paturilor.

7. Daina L. Manual de management sanitar. Editura Universităţii din Oradea, 2007.

8. Soltan V. Studiul politicii privind gradul descentralizării administrative în domeniul sănătăţii publice, Raport final, Centrul pentru politici şi analize în Sănătate 2009, Chişinău.

9. Armean P. Managementul calităţii serviciilor de sănătate. Bucureşti: Editura Coresi, 2002

10. Saltman RB, Bankauskaite V, Vrangbaek K. Decentralization in Health Care: Strategies and Outcomes. England: Open University Press, 2007.

\section{CONCLUZII}

Sistemele de sănătate, indiferent de țară, care se bazează pe finanţare cu preponderenţă de la Bugetul de stat, se constituie ca sisteme naţionale de sănătate.

În România, ulterior procesului de descentralizare din anul 2010, când managementul medical a fost cedat de la nivel central la nivelul administraţiilor publice locale, spitalele de stat au rămas în continuare subfinanţate. De fapt, descentralizarea managementului medical nu a schimbat, în esenţă, modalitatea de finanţare existentă în cadrul unui sistem medical centralizat.

În Australia, ţară din care România a ,importat“" sistemul de finanţare a bugetelor spitalelor, există, de asemenea, o subfinanţare a domeniului medical. Ca urmare, sistemul DRG, funcţionabil sub forme diferite şi adaptat fiecărei ţări în parte, este perfectibil şi supus în continuare la ajustări şi îmbunătăţiri.

11. Armean $P$. Management sanitar. Noţiuni fundamentale de sănătate publică. Bucureşti: Editura Coresi, 2004.

12. Hotărârea de guvern 562/2009 - Strategia de descentralizare in sistemul de sănătate, Anexa: Capitolul I.

13. Sheiman I, Shishkin S, Shevsky V. The evolving Semashko model of primary health care: the case of the Russian Federation. Risk Manag Healthc Policy. 2018 Nov 2;11:209-220.

14. Light DW. Universal health care: lessons from the British experience. Am J Public Health. 2003 Jan;93(1):25-30.

15. Vlădescu C. Sănătate Publică şi Management Sanitar. Bucureşti: Cartea Universitară, 2004.

16. Armean P. Politici şi sisteme de sănătate europene. Bucureşti: Editura Curtea Veche, 2005.

17. https://umfcd.ro/wp-content/uploads/2016/11/Finatarea_sistemelor_ de_sanatate-315-337.pdf.

18. https://www.medichub.ro/reviste/medic-ro/public-versus-privat-in-sanatate-id-1661-cmsid-51. Public versus privat în sănătate. Vasile Astărăstoae. Busola morală, 29 aprilie 2018.

19. http://www.drg.ro/Doc/australiaro.doc.

20. www.health.gov.au/casemix - Australian Casemix.

21. Regmi K. Decentralizing Health Services: A Global Perspective. Springer Science+Bussiness Media New York, 2007.

22. http://cnpv.ro/wp-content/uploads/2020/03/studiu_finantare_sanatate_2011.pdf. 